\title{
The Predictive Factors and Maternal and Foetal Outcome of Breech Delivery in Rangpur Medical College Hospital
}

\author{
Dr. Sonali Rani Mustofi ${ }^{1 *}$, Professor Dr. Ranjit Basak ${ }^{2}$, Professor Dr. Ferdousi Sultana ${ }^{3}$, Dr. Abu Zafar Al Murad ${ }^{4}$ \\ ${ }^{1}$ Assiatant Professor, Department of Gynaecology and Obstetrics, Prime Medical College, Rangpur, Bangladesh \\ ${ }^{2}$ Professor, Department of Paediatrics, Community Medical College, Rangpur, Bangladesh \\ ${ }^{3}$ Professor and Head, Department of Gynaecology and Obstetrics, Rangpur Medical College, Rangpur, Bangladesh \\ ${ }^{4}$ Registarar, Community Medical College, Rangpur, Bangladesh
}

DOI: $10.36348 /$ sijog.2021.v04i01.003

| Received: 30.12 .2020 | Accepted: 13.01.2021 | Published: 19.01.2021

*Corresponding author: Dr. Sonali Rani Mustofi

Abstract

Objective: In this study our main goal is to evaluate the predictive factors and maternal and foetal outcome of breech delivery in Rangpur medical college hospital. Method: This prospective observational study was carried out at Rangpur medical college hospital. From July 2019-Deccember 2019 where 51 singleton uncomplicated breech presentation admitted for delivery were included in the study. Results: During the study, mean umbilical cord length in LSCS and vaginal delivery group was $55.3 \pm 3.8 \mathrm{~cm}$ and $56.2 \pm 3.7 \mathrm{~cm}$ respectively. Mean placental weight in breech deliveries in LUCS and vaginal delivery group was $645 \pm 132$ gram and $599 \pm 212$ respectively. Cornu-fundus position of placental localization was the commonest in both the groups. Regarding the fetal outcome, $42.1 \%$ neonates suffered birth asphyxia in vaginal group while $37.5 \%$ suffered same problem in LUCS group. Higher $(62.5 \%)$ percentage of children was born in LUCS group without any complications compared to $52.6 \%$ in vaginal group. Higher percentage $(42.1 \%)$ of neonates needed admission in vaginal delivery group than LUCS group (37.5\%) for different complications. $87.5 \%$ of LUCS group and $57.8 \%$ in vaginal group did not suffer from any maternal complications during delivery. No mortality was reported. Conclusion: From our study we can conclude that, short umbilical cord length and increased placental weight may be the important predictive factors for breech presentation.

Keywords: Breech delivery, maternal and foetal outcome, vaginal delivery.

Copyright (C) 2021 The Author(s): This is an open-access article distributed under the terms of the Creative Commons Attribution 4.0 International License (CC BY-NC 4.0) which permits unrestricted use, distribution, and reproduction in any medium for non-commercial use provided the original author and source are credited.

\section{INTRODUCTION}

Breech is the commonest mal-presentation which is defined as the initial entrance of the gluteal region, rather than cephalic region, of the fetus into maternal pelvis. The incidence of breech presentation is $25 \%$ before week $28,7 \%$ at week 32 and $3-4 \%$ at $38-40$ weeks of gestation [1-3].

In pregnancies complicated by breech presentation, perinatal mortality, neonatal mortality or serious neonatal morbidity is increased as compared to pregnancies where the fetes are in cephalic position [24]. The incidence of breech delivery is higher in lowbirth weight fetuses ${ }^{1}$ when spontaneous conversion to cephalic presentation is prevented as term approaches or if labor and delivery occur prematurely before cephalic version has taken place $[2,5]$.
Prematurity, multiple gestations, advanced multi-parity, fetal anomalies, uterine anomalies and pelvic tumors are considered as common associated factors [1, 6-8] In addition, placental localization, greater maternal weight, greater placental weight, shorter umbilical cord length is thought to be commoner predictive factors [1,9-12]. But unfortunately, there is no collective data in our country to draw any conclusive idea.

In this study our main goal is to evaluate the predictive factors and maternal and foetal outcome of breech delivery in Rangpur medical college hospital.

\section{OBJECTIVE}

- To assess the predictive factors and maternal and foetal outcome of breech delivery in Rangpur medical college hospital. 


\section{METHODOLOGY}

\section{Study type}

- This was a prospective observational study.

\section{Study Population}

- Term singleton uncomplicated breech presentation admitted for delivery.

\section{Study Place}

- Study was done in a single maternity unit of Rangpur Medical College Hospital which is a tertiary care hospital.

\section{Duration}

- Total study period was around 6 months (July 2019-Deccember 2019)

\section{Sampling method}

- Purposive sampling was used in the study.

\section{Study tool}

- The patients or relatives were interviewed using self-administered structured questionnaires at admission.

\section{Sample size}

- With the desired precision and level of confidence, the calculated sample size would be bigger. Due to limitation of time, 51 cases were taken for conducting the study.

\section{Sampling technique}

- Samples would be selected considering inclusion and exclusion criteria among the pregnant women presented with breech presentation. Those who gave informed written consent were finally enrolled in this study.

\section{Inclusion criteria}

- Breech presentation from 37 to 42 weeks of gestation.

- Breech without any complications

\section{Exclusion criteria}

- Multiple pregnancies

- Intra-uterine death (IUD)

\section{Data collection procedure}

- After admission, patients were enrolled in this study after written informed consent. History was taken from the patient or her attendance which was applicable. Breech presentation was confirmed by clinical examination and/or ultrasonography. All the relevant physical and clinical information was noted in the structured questionnaire. Maternal and fetal condition was monitored carefully throughout the delivery. After the delivery, mother and the baby were followed up till discharge. Necessary data were noted.

\section{DATA ANALYSIS}

- Data were analyzed by SPSS version 12.0 . Qualitative data were analyzed as rate \& percentage. Quantitative data were analyzed by mean \& standard deviation.

\section{RESULTS}

In figure-1 shows distribution of the age according to different modes of delivery. The mean age of the patients delivered by caesarean section was $25.50 \pm 4.9$ and vaginal delivery was $25.53 \pm 5.2$ respectively. The following table is given below in detail:

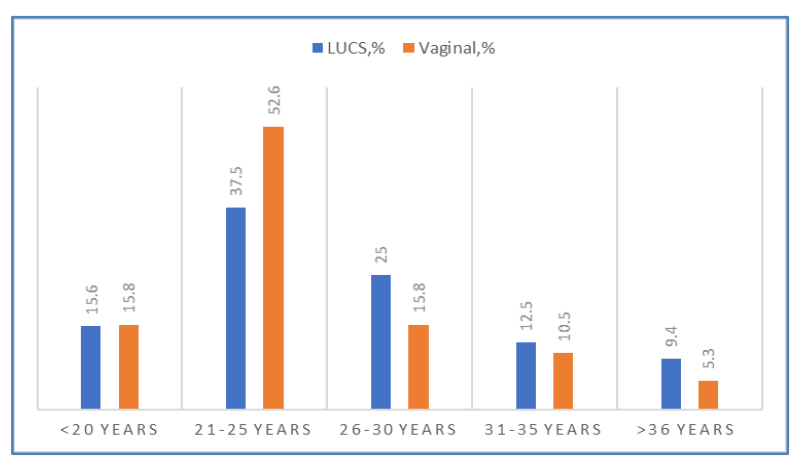

Fig-1: Frequency distribution of age and different modes of delivery

In table-1 shows comparison between height distribution and different modes of delivery. Mean height in LUCS and vaginal delivery group was $152.5 \pm 2.8 \mathrm{~cm}$ and $154.2 \pm 3.7 \mathrm{~cm}$ respectively. Also, mean weight in LUCS and vaginal delivery group was $66.3 \pm 5.8 \mathrm{~kg}$ and $67.2 \pm 5.7 \mathrm{~kg}$ respectively. The following table is given below in detail: 
Sonali Rani Mustofi et al; Sch Int J Obstet Gynec, Jan. 2021; 4(1): 11-16

Table-1: Comparison between height distribution and different modes of delivery

\begin{tabular}{|c|c|c|c|c|c|c|}
\hline \multirow{2}{*}{$\begin{array}{l}\text { Height } \\
\text { (cm) }\end{array}$} & \multicolumn{3}{|c|}{ LUCS (n=32) } & \multicolumn{3}{|c|}{ Vaginal $(n=19)$} \\
\hline & Number & Percentage (\%) & Mean \pm SD & Number & Percentage (\%) & Mean \pm SD \\
\hline$<152$ & 12 & 37.5 & \multirow[t]{3}{*}{$152.5 \pm 2.8$} & 04 & 21.1 & \multirow[t]{3}{*}{$154.2 \pm 3.7$} \\
\hline $152-158$ & 17 & 53.1 & & 10 & 52.6 & \\
\hline$>158$ & 03 & 9.4 & & 05 & 26.3 & \\
\hline \multirow{2}{*}{$\begin{array}{l}\text { Weight } \\
(\mathrm{kg})\end{array}$} & \multicolumn{3}{|c|}{ LUCS $(n=32)$} & \multicolumn{3}{|c|}{ Vaginal $(n=19)$} \\
\hline & Number & Percentage $(\%)$ & Mean \pm SD & Number & Percentage $(\%)$ & Mean \pm SD \\
\hline$<60$ & 05 & 15.6 & \multirow[t]{3}{*}{$66.3 \pm 5.8$} & 02 & 10.5 & \multirow[t]{3}{*}{$67.2 \pm 5.7$} \\
\hline $60-70$ & 17 & 53.1 & & 14 & 73.7 & \\
\hline$>70$ & 10 & 31.3 & & 03 & 15.8 & \\
\hline
\end{tabular}

In table-2 shows comparison between length of the umbilical cord length and different modes of delivery. Mean umbilical cord length in LSCS and vaginal delivery group was $55.3 \pm 3.8 \mathrm{~cm}$ and $56.2 \pm 3.7$ $\mathrm{cm}$ respectively.

Table-2: Comparison between length of the umbilical cord length and different modes of delivery

\begin{tabular}{|c|c|c|c|c|c|c|}
\hline \multirow{2}{*}{$\begin{array}{l}\text { Length } \\
\text { (cm) }\end{array}$} & \multicolumn{3}{|c|}{$\operatorname{LSCS}(\mathbf{n}=32)$} & \multicolumn{3}{|c|}{ Vaginal $(n=19)$} \\
\hline & Number & Percentage (\%) & Mean \pm SD & Number & Percentage (\%) & Mean \pm SD \\
\hline$<40$ & 02 & 6.2 & \multirow[t]{3}{*}{$55.3 \pm 3.8$} & 02 & 10.5 & \multirow[t]{3}{*}{$56.2 \pm 3.7$} \\
\hline $40-60$ & 23 & 71.9 & & 16 & 84.2 & \\
\hline$>60$ & 07 & 21.9 & & 01 & 5.3 & \\
\hline
\end{tabular}

In table-3 shows comparison between fetal outcome and different modes of delivery. Regarding the fetal outcome, $42.1 \%$ neonates suffered birth asphyxia in vaginal group while $37.5 \%$ suffered same problem in LUCS group. Higher $(62.5 \%)$ percentage of children was born in LUCS group without any complications compared to $52.6 \%$ in vaginal group. The following table is given below in detail:

Table-3: Comparison between fetal outcome and different modes of delivery

\begin{tabular}{|l|l|l|l|l|}
\hline \multirow{2}{*}{ Fetal Outcome } & \multicolumn{2}{|l|}{ LUCS $(\mathbf{n}=\mathbf{3 2})$} & \multicolumn{2}{l|}{ Vaginal $(\mathbf{n}=19)$} \\
\cline { 2 - 5 } & Number & Percentage & Number & Percentage \\
\hline Live birth without complications & 20 & 62.5 & 10 & 52.6 \\
\hline Still birth & 00 & 00 & 01 & 5.3 \\
\hline Birth asphyxia & 12 & 37.5 & 08 & 42.1 \\
\hline Birth trauma & 00 & 00 & 02 & 10.5 \\
\hline Neonatal death & 03 & 9.4 & 02 & 10.5 \\
\hline
\end{tabular}

In table-4 shows comparison between placental weights and its localization and different modes of delivery. Mean placental weight in breech deliveries in LUCS and vaginal delivery group was
$645 \pm 132$ gram and 599 \pm 212 respectively. Cornu-fundus position of placental localization was the commonest in both the groups. The following table is given below in detail:

Table-4: Comparison between placental weights and its localization and different modes of delivery

\begin{tabular}{|l|l|l|}
\hline Variables & LUCS $(\mathbf{n}=32)$ & Vaginal $(\mathbf{n}=19)$ \\
\hline Placental weight, gm (Mean \pm SD) & $645 \pm 132$ & $599 \pm 212$ \\
\hline Placental localizations, n (\%) & $21(65.6)$ & $14(73.7)$ \\
\hline Cornu-fundus & $5(15.7)$ & $2(10.5)$ \\
\hline Anterior wall & $3(9.4)$ & $2(10.5)$ \\
\hline Posterior wall & $2(6.2)$ & $1(5.3)$ \\
\hline Right side wall & $1(3.1)$ & $0(0.0)$ \\
\hline Left side wall & & \\
\hline
\end{tabular}

In table-5 shows comparison between causes of neonatal admission and different modes of delivery in breech presentation. Majority of the neonates admitted in neonatal ward due to birth asphyxia in both of the groups. $91.7 \%$ versus $75 \%$ in LUCS group and vaginal group respectively. The following table is given below in detail: 
Sonali Rani Mustofi et al; Sch Int J Obstet Gynec, Jan. 2021; 4(1): 11-16

Table-5: Comparison between causes of neonatal admission and different modes of delivery in breech presentation

\begin{tabular}{|l|l|l|l|l|}
\hline \multirow{2}{*}{$\begin{array}{l}\text { Causes: } \\
\text { Neonatal admission }\end{array}$} & \multicolumn{2}{|l|}{ LUCS (n=32) } & \multicolumn{2}{l|}{ Vaginal (n=19) } \\
\cline { 2 - 5 } & Number & Percentage & Number & Percentage \\
\hline Birth Asphyxia & 11 & 91.7 & 06 & 75.0 \\
\hline Birth trauma & 00 & 00 & 02 & 25.0 \\
\hline Physiological jaundice & 01 & 8.3 & 00 & 00 \\
\hline Umbilical sepsis & 00 & 00 & 00 & 00 \\
\hline Neonatal sepsis & 00 & 00 & 00 & 00 \\
\hline
\end{tabular}

In table-6 shows comparison between Apgar score and different modes of delivery in breech presentation. Apgar score of (0-6) was seen in $37.5 \%$ in
LUCS group and $42.1 \%$ in vaginal group. At 5th minute, $34.4 \%$ of LUCS and $31.6 \%$ of vaginal group had scored below 7 . The following table is given below:

Table-6: Comparison between Apgar score and different modes of delivery in breech presentation

\begin{tabular}{|l|l|l|l|l|}
\hline \multirow{2}{*}{$\begin{array}{l}\text { Apgar } \\
\text { Score }\end{array}$} & \multicolumn{2}{|c|}{ LUCS $(\mathbf{n}=32)$} & \multicolumn{2}{c|}{ Vaginal $(\mathbf{n}=19)$} \\
\cline { 2 - 5 } & Number & Percentage & Number & Percentage \\
\hline At $1^{\text {st }}$ minute & & & & \\
$0-6$ & 12 & 37.5 & 08 & 42.1 \\
$7-10$ & 20 & 62.5 & 11 & 57.9 \\
\hline At $5^{\text {th }}$ Minute & & & & \\
$0-6$ & 11 & 34.4 & 06 & 31.6 \\
$7-10$ & 21 & 65.6 & 13 & 68.4 \\
\hline
\end{tabular}

In figure-2 shows comparison between fetal weight and different modes of delivery in breech presentation. $9.4 \%$ of babies of LUCS group had birth weight more than $3.5 \mathrm{~kg}$ but no babies born in vaginal group with weight above $3.5 \mathrm{~kg}$. The following figure is given below in detail:

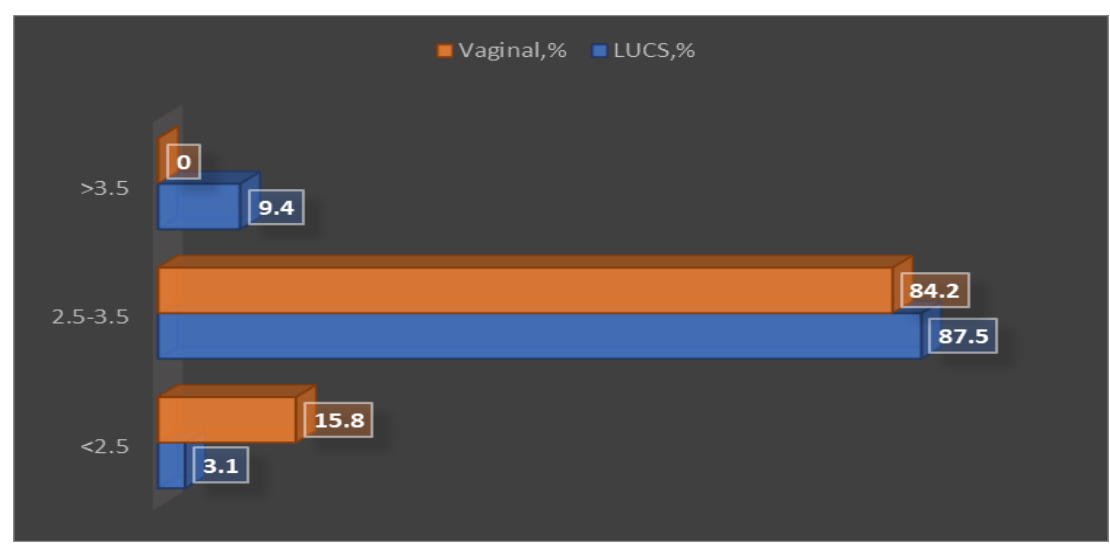

Fig-2: Comparison between fetal weight and different modes of delivery in breech presentation

In table-7 shows distribution of maternal complications during delivery and different modes of delivery in breech presentation.87.5\% of LUCS group and $57.8 \%$ in vaginal group did not suffer from any maternal complications during delivery. No mortality was reported. The following table is given below in detail:

Table-7: Distribution of maternal complications during delivery and different modes of delivery in breech presentation

\begin{tabular}{|l|l|l|l|l|}
\hline \multirow{2}{*}{$\begin{array}{l}\text { Complications } \\
\text { during delivery }\end{array}$} & \multicolumn{2}{|l|}{ LUCS $(\mathbf{n}=\mathbf{3 2})$} & \multicolumn{2}{l|}{ Vaginal (n=19) } \\
\cline { 2 - 5 } & Number & Percentage & Number & Percentage \\
\hline None & 28 & 87.5 & 11 & 57.8 \\
\hline PPH & 03 & 9.4 & 01 & 5.3 \\
\hline Retained placenta & 00 & 00 & 01 & 5.3 \\
\hline Genital tract injury & 00 & 00 & 06 & 31.6 \\
\hline Anaesthetic complications & 01 & 3.1 & 00 & 00 \\
\hline Shock & 00 & 00 & 00 & 00 \\
\hline Others & 00 & 00 & 00 & 00 \\
\hline
\end{tabular}


Sonali Rani Mustofi et al; Sch Int J Obstet Gynec, Jan. 2021; 4(1): 11-16

In table- 8 shows maternal complications were higher in LUCS group compared to vaginal group. Wound infection was the commonest complication in
LUCS group. The following table is given below in detail:

Table-8: Maternal complications during puerperium and correlation with different modes of delivery

\begin{tabular}{|l|l|l|l|l|}
\hline \multirow{2}{*}{$\begin{array}{l}\text { Complications } \\
\text { during puerperium }\end{array}$} & \multicolumn{2}{l|}{ LUCS $(\mathbf{n}=32)$} & \multicolumn{2}{l|}{ Vaginal $(\mathbf{n}=19)$} \\
\cline { 2 - 5 } & Number & Percentage & Number & Percentage \\
\hline None & 22 & 68.5 & 15 & 78.9 \\
\hline Secondary PPH & 01 & 3.2 & 02 & 10.5 \\
\hline Fever & 02 & 6.3 & 01 & 5.3 \\
\hline UTI & 01 & 3.2 & 00 & 00 \\
\hline Wound infection & 06 & 18.8 & 01 & 5.3 \\
\hline
\end{tabular}

\section{DISCUSSION}

Neonatal mortality accounted for $9.4 \%$ in LSCS group and $10.5 \%$ in vaginal group in this study. Whereas one study reported $0.8 \%$ neonatal mortality in caesarean delivery and $5.79 \%$ in vaginal breech delivery [13]. This relatively high mortality was probably due to heavy patients' load despite prompt and appropriate intervention in neonatal care unit. Neonatal mortality has been used traditionally as a measure of the quality of care. Recently neonatal morbidity is being taken into account to assess the burden of the disease. It is estimated that $62.5 \%$ in caesarean group and $52.6 \%$ in vaginal group had no fetal morbidity. This good outcome may be the reflection of ready availability of emergency obstetric services. Birth asphyxia was accounted as a major disease burden in both the groups of breech presentation.

The umbilical cord is, on the average, 55 to 61 $\mathrm{cm}$ in length at term, which is sufficient length for a vaginal delivery to be accomplished with a fundal implantation of the placenta $[14,15]$.

In one study, in which 1,000 cases were observed, found the average umbilical cord length to be $51 \mathrm{~cm}$ (range 15-130 cm), and also found that breech fetuses had shorter umbilical cords than those of cephalic fetuses [16]. In addition, in this study, mean umbilical cord length in LSCS and vaginal delivery group was $55.3 \pm 3.8 \mathrm{~cm}$ and $56.2 \pm 3.7 \mathrm{~cm}$ respectively. This finding coincides with the findings of the previously mentioned literature that suggests relatively short umbilical cord can be a predictive factor for breech presentation.

The ability of the fetus to grow and thrive in utero is presumed to be a function of the placenta. The placenta at term is, on average, $185 \mathrm{~mm}$ in diameter and $23 \mathrm{~mm}$ in thickness, with an average volume of $497 \mathrm{ml}$, and a weight of 508 gram [17]. In this study, mean placental weight in breech deliveries in LSCS and vaginal delivery group was $645 \pm 132$ gram and $599 \pm 212$ gram respectively (Table-9). Similar findings were observed by one study that suggested mean placental weight in the breech group was significantly higher (657, range 320-1280 gram) [1]. So, higher placental weight can be considered as an important predictive factor for breech presentation. Cornu-fundal position of placental localization was the commonest in both the groups in this study that was supported by some different authors $[1,10,12]$.

Like neonates, maternal mortality and morbidity is considered as the good indicator for a quality care. Only $9.4 \%$ of mother in LSCS group and $5.3 \%$ of the vaginal group suffered from post-partum hemorrhage (PPH), none of them had no major casualties. PPH is considered as a leading cause of maternal morbidity and mortality worldwide [18].

This low figure in this study reflected the prompt and appropriate intervention given to the patients in order to prevent mortality due to hemorrhage in a tertiary setting. Genital tract injuries were $31.6 \%$ in vaginal group, but no such injury was reported in caesarean delivery group. On the other hand, single case $(3.1 \%)$ of anesthetic complication was noted in LSCS group, but not in vaginal group. Again, $87.5 \%$ in LSCS group and $57.8 \%$ in vaginal delivery group did not suffer from any type of maternal complications during delivery process that reflected better obstetrical care.

Unlike another study by, maternal complications in puerperium were $28.2 \%$ versus $13.4 \%$ in LSCS and in vaginal group respectively [6]. These higher values may be due to excess patient load and lack of necessary resources even in the tertiary hospital. Maternal morbidity was high with caesarean section where wound infection and fever were the commonest maternal ailments. Mother with vaginal deliveries suffered comparatively less in puerperium.

\section{CONCLUSION}

From our study we can conclude that, short umbilical cord length and increased placental weight may be the important predictive factors for breech presentation.

\section{REFERENCE}

1. Talas, B. B., Altinkaya, S. O., Talas, H., Danisman, N., \& Gungor, T. (2008). Predictive factors and 
short-term fetal outcomes of breech presentation: a case-control study. Taiwanese Journal of Obstetrics and Gynecology, 47(4), 402-407.

2. Vlemmix, F., Rosman, N.A., Fleuren, H.A.M., Rijnders, E.B.M., Beuckens, A., Haak, C.M. (2010). Inplementation of thec external cephalic version in breech delivery. Dutch national implementation study of external cephalic version.BMC Pregnancy and Childbirth, 10:20.

3. Hannah, M. E., Hannah, W. J., Hewson, S. A., Hodnett, E. D., Saigal, S., Willan, A. R., \& Collaborative, T. B. T. (2000). Planned caesarean section versus planned vaginal birth for breech presentation at term: a randomised multicentre trial. The Lancet, 356(9239), 1375-1383.

4. Danielian, P. J., Wang, J., \& Hall, M. H. (1996). Long term outcome by method of delivery of fetuses in breech presentation at term: population based follow up. Bmj, 312(7044), 1451-1453.

5. Kish, K., Collea, J.V. (2003). Malpresentation and cord prolapse. In: DeCherney AH, Nathan L, eds. Current Obstetric and Gynaecologic Diagnosis and Treatment, $9^{\text {th }}$ edition. New York: McGraw-Hill, 369-86.

6. Nordtveit, T. I., Melve, K. K., Albrechtsen, S., \& Skjaerven, R. (2008). Maternal and paternal contribution to intergenerational recurrence of breech delivery: population based cohort study. Bmj, 336(7649), 872-876.

7. Pajntar, M., Verdenik, I., \& Pestevšek, M. (1994). Cesarean section in breech by birth weight. European Journal of Obstetrics \& Gynecology and Reproductive Biology, 54(3), 181184.

8. Dunn, L. J., VAN VOORHIS, L. E. E., \& NAPIER, J. (1965). Term Breech Presentation A Report of 499 Consecutive Cases. Obstetrics \& Gynecology, 25(2), 170-176.

9. Katsumata, T., Miyake, A., Aki, T., Hirooka, K., Hayashida, M., Toyoda, M., \& Tanizawa, O. (1991). Length of the human umbilical cord in multiple pregnancy. European Journal of Obstetrics
\& Gynecology and Reproductive Biology, 40(1), 25-27.

10. Fianu, S., \& Václavinková, V. (1978). The site of placental attachment as a factor in the aetiology of breech presentation. Acta obstetricia et gynecologica Scandinavica, 57(4), 371-372.

11. Adinma, J. I. (1993). The umbilical cord: a study of 1,000 consecutive deliveries. International journal of fertility and menopausal studies, 38(3), 175.

12. Filipov, E., Borisov, I., \& Kolarov, G. (2000). Placental location and its influence on the position of the fetus in the uterus. Akusherstvo i ginekologiia, 40(4), 11-12.

13. Erkaya, S., Tuncer, R. A., Kutlar, I., Onat, N., \& Ercakmak, S. (1997). Outcome of 1040 consecutive breech deliveries: clinical experience of a maternity hospital in Turkey. International Journal of Gynecology \& Obstetrics, 59(2), 115118.

14. Mills, J. L., Harley, E. E., \& Moessinger, A. C. (1983). Standards for measuring umbilical cord length. Placenta, 4(4), 423-426.

15. Baergen, R. N. (2007, February). Cord abnormalities, structural lesions, and cord "accidents". In Seminars in diagnostic pathology. WB Saunders, 24(1): 23-32

16. Janthanaphan, M., Kor-anantakul, O., \& Geater, A. (2006). Placental weight and its ratio to birth weight in normal pregnancy at Songkhlanagarind Hospital. Journal-medical association of thailand, 89(2), 130.

17. Janthanaphan, M., Kor-anantakul, O., \& Geater, A. (2006). Placental weight and its ratio to birth weight in normal pregnancy at Songkhlanagarind Hospital. Journal-medical association of thailand, 89(2), 130.

18. Henry, A., BIRCH, M. R., Sullivan, E. A., Katz, S., \& Wang, Y. A. (2005). Primary postpartum haemorrhage in an Australian tertiary hospital: a case- control study. Australian and New Zealand journal of obstetrics and gynaecology, 45(3), 233236. 